\title{
A COMPARISON OF THE PROPERTIES OF KLEBSIELLA STRAINS ISOLATED FROM DIFFERENT SOURCES
}

\author{
A. S. Edmondson, E. Mary Cooke, A. P. D. Wilcock \\ AND RUTH SHINEBAUM \\ Department of Microbiology, School of Medicine, University of Leeds, Leeds LS2 9NL
}

KLEBSIELLAS are often found in the human bowel and in a variety of environmental situations, such as soil, vegetation and water (Duncan and Razzell, 1972; Knittel, 1975). Over the last two decades klebsiellas have become important opportunistic pathogens in hospital patients (Price and Sleigh, 1970; Curie et al., 1978) and have been frequently associated with animal diseases such as bovine mastitis (Braman et al., 1973).

Despite the availability of good typing methods, such as capsular serotyping and bacteriocine typing, the epidemiology of klebsiella infections is not fully understood, and little is known of the significance of environmentally derived strains in causing infections in hospital patients. Some previous investigations suggested that klebsiellas isolated from human and animal infections are phenotypically indistinguishable from environmental strains (Brown and Seidler, 1973; Dufour and Cabelli, 1976), but DNA-reassociation studies indicated that environmentally derived strains are genetically more diverse than strains of clinical origin (Seidler, Knittel and Brown, 1975). More recently, Naemura and Seidler (1978) showed that klebsiellas of clinical origin can be distinguished from environmentally derived strains by tests of the so-called "faecal coliform" (FC) response (that is, the production of acid and gas in lactose bile-salt broth at $44.5^{\circ} \mathrm{C}$ ), growth in nutrient broth at $10^{\circ} \mathrm{C}$, indole production and pectin liquefaction.

We have examined these four properties and some others in klebsiella strains isolated from human and animal infections, from human faeces, and from environmental sites within and outside hospital. We hoped in this way to clarify the significance of environmentally derived klebsiellas in human infection.

\section{MATERIALS AND METHODS}

\section{Sources of strains examined}

The strains that were accepted as klebsiellas had the following characters (see Edmondson and Cooke, 1979): non-motile, acid produced from inositol, hydrogen sulphide not produced (Donovan, 1966), acid produced from adonitol, urea hydrolysed, no ornithine decarboxylase.

In all, 480 klebsiella strains were examined: 113 were from various human infections and 10 from cases of mastitis in pigs; 40 were from the faeces of patients in hospital who were suffering 
from klebsiella infection and 40 from the faeces of outpatients who had no known infection; 49 were from the environment of hospital wards; 48 were from the environment of a hospital kitchen and 50 from food prepared in this kitchen; 50 were from flowers in vases in a hospital and 33 from flowers purchased from 20 florists' shops in the Leeds area; and 38 were from samples of river water.

The strains from clinical specimens in patients, faeces, ward and kitchen environment and food were isolated as described by Cooke et al. (1979 $a$ and $b, 1980)$. Strains from pig mastitis were kindly provided by Dr J. E. T. Jones, The Royal Veterinary College, Potters Bar, Herts.

Samples of river water were collected from nine sources ranging from sites remote from human habitation to those close to housing and heavy industry. The water was filtered through $0.45-\mu \mathrm{m}$ membrane filters which were then placed on Eosin-Methylene Blue Agar (Oxoid) and incubated at $37^{\circ} \mathrm{C}$ for $48 \mathrm{~h}$ and at $25^{\circ} \mathrm{C}$ for 5 days. Colonies with the morphological appearance of klebsiellas were selected and identified biochemically as previously (Edmondson and Cooke, 1979).

Flowers were sampled by adding $100 \mathrm{ml}$ of one-quarter strength Ringer's solution to $20 \mathrm{~g}$ of flowers in a sterile plastic bag, and agitating the bag manually for 2-3 min. Ten $\mathrm{ml}$ of the resulting liquid were added to each of five tubes containing $10 \mathrm{ml}$ of double-strength Minerals Modified Glutamate (MMG) Broth (Oxoid), and $1 \mathrm{ml}$ was added to each of five tubes containing $5 \mathrm{ml}$ of single-strength MMG broth. The tubes were incubated at $37^{\circ} \mathrm{C}$ for $48 \mathrm{~h}$ and all tubes showing acid and gas production were subcultured to MacConkey's agar and to this medium with the addition of inositol and carbenicillin (Cooke et al., 1979a). Klebsiella colonies were picked from the plates, colonies with different morphology being selected when possible.

\section{Tests performed}

The FC reaction. Strains were inoculated to $5 \mathrm{ml}$ of Nutrient Broth (Oxoid) which contained lactose $1 \% \mathrm{w} / \mathrm{v}$ and phenol red $0.002 \% \mathrm{w} / \mathrm{v}$ and were incubated at $35^{\circ}$ for $24 \mathrm{~h}$. Subcultures were then made to "elevated coliform" (EC) broth (American Public Health Association, 1976) which contained: Tryptone (Difco), $20 \mathrm{~g}$; lactose, $5 \mathrm{~g}$; Bile Salts No. 3 (Oxoid), $1.5 \mathrm{~g}$; dipotassium hydrogen phosphate, $4 \mathrm{~g}$; potassium dihydrogen phosphate, $1.5 \mathrm{~g}$; sodium chloride, $5 \mathrm{~g}$; distilled water, 1 litre. EC-broth cultures were incubated at $44 \cdot 5 \pm 0.2^{\circ} \mathrm{C}$ for $18 \mathrm{~h}$, and tubes showing both turbidity and gas production were recorded as FC positive.

Growth at $10^{\circ} \mathrm{C}$. Strains were inoculated into $5 \mathrm{ml}$ of Nutrient Broth (Oxoid) and incubated at $37^{\circ} \mathrm{C}$ for $18 \mathrm{~h}$. These cultures were subcultured to $5 \mathrm{ml}$ of fresh Nutrient Broth (Oxoid) in screw-capped test tubes to give a final dilution of 1 in 5000. The tubes were incubated in a stationary water bath at $10 \pm 0.2^{\circ} \mathrm{C}$ for $96 \mathrm{~h}, 0.1 \mathrm{ml}$ of formalin was added to each tube and the tubes were left at $4^{\circ} \mathrm{C}$ for $1 \mathrm{~h}$. The optical density of each culture was measured at $600 \mathrm{~nm}$ by means of a SP6-200 spectrophotometer (Pye Unicam Ltd, Cambridge), and growth was considered to have occurred when the optical density was greater than 0.02 . This optical density represented a 100 -fold increase on the initial inoculum.

Indole reaction. The production of indole was determined as described by Cowan (1974).

Pectin liquefaction. Liquefaction of pectin was detected on an agar medium modified from that described by Edwards and Ewing (1972) and containing yeast extract (Difco) $5 \mathrm{~g}$, sodium polypectate (Sigma) $15 \mathrm{~g}$, agar (Oxoid) $15 \mathrm{~g}, 1.0 \mathrm{~N}$ sodium hydroxide solution $9 \mathrm{ml}, 10 \%(\mathrm{w} / \mathrm{v})$ calcium chloride solution $5 \mathrm{ml}, 0.2 \% \mathrm{w} / \mathrm{v}$ aqueous bromothymol blue $12.5 \mathrm{ml}$, distilled water 1 litre. The medium was distributed into plates and cultures were heavily inoculated over an area of $1 \mathrm{~cm}^{2}$; six cultures were inoculated per plate. After incubation at $37^{\circ} \mathrm{C}$ for $48 \mathrm{~h}$, pectin liquefaction was observed by sinking of the colony into the agar.

Gelatin hydrolysis. Hydrolysis of nutrient gelatin was detected as described by Cowan (1974). Nutrient-gelatin stab cultures were incubated at $25^{\circ} \mathrm{C}$ and observed at weekly intervals for 3 months. Strains of Escherichia coli, Enterobacter aerogenes and Serratia marcescens were used as controls in these tests.

Capsular serotyping was performed by the quellung reaction as previously (Edmondson and Cooke, 1979) with the use of 78 capsular antisera produced in this laboratory. 
Bacteriocine typing was by the method of Edmondson and Cooke (1979).

Sensitivity to antibiotics was tested by the method of Stokes (1975) and the results were recorded as resistant, moderately resistant or sensitive. The antibiotics used were (per disk): ampicillin $10 \mu \mathrm{g}$, chloramphenicol $10 \mu \mathrm{g}$, streptomycin $10 \mu \mathrm{g}$, sulphafurazole $100 \mu \mathrm{g}$, tetracycline $10 \mu \mathrm{g}$, nalidixic acid $30 \mu \mathrm{g}$, cephalothin $30 \mu \mathrm{g}$, gentamicin $10 \mu \mathrm{g}$, kanamycin $30 \mu \mathrm{g}$, nitrofurantoin $200 \mu \mathrm{g}$.

\section{RESULTS}

Tests of $\mathrm{FC}$ reaction, growth at $10^{\circ} \mathrm{C}$, indole production and pectin liquefaction

Only five of the 16 possible groups were represented amongst the 480 klebsiella strains tested for $\mathrm{FC}$ reaction, growth at $10^{\circ} \mathrm{C}$, indole production and pectin liquefaction. No strains both gave a positive $\mathrm{FC}$ response and grew at $10^{\circ} \mathrm{C}$; no strains that were $\mathrm{FC}$ positive, and none that failed to grow at $10^{\circ} \mathrm{C}$, produced indole or liquefied pectin; and no indole-negative strains liquefied pectin. These exclusions left the five groups shown in table 1. The majority of strains of clinical origin were FC positive and negative in the other three tests, and were thus contained in group 1. Strains in groups 2,3 and 4 were all FC negative and usually came from the environment, but strains from any one environmental source were equally likely to belong to any one of these groups. Only nine strains gave a negative response in each test (group 5); they had been isolated from the following sources: human infections (3), hospital environment (1), flowers from florists (1), natural environment (2) and hospitalkitchen environment (2).

The results of the $\mathrm{FC}$, growth at $10^{\circ} \mathrm{C}$, indole-production and pectin-liquefaction tests for strains grouped according to their source (see Materials and methods) are given in table II. The nine strains that gave negative reactions in all four tests are omitted from the table. Strains from the various sources showed significant differences in the proportion with positive $\mathrm{FC}$ reaction and no growth at $10^{\circ} \mathrm{C}\left(\chi^{2}=124.94 ; 9\right.$ degrees of freedom; $\left.p<0.001\right)$. There is a significant decrease in proportions of FC-positive strains as the source becomes more like the natural environment, when the sources are ranked as in

TABLE I

Groups of klebsiella strains defined by reactions in four tests

\begin{tabular}{ccccc|c}
\hline \multicolumn{5}{c|}{ Reaction in test } & \\
\cline { 2 - 5 } $\begin{array}{c}\text { Group } \\
\text { no. }\end{array}$ & FC* $^{*} \begin{array}{c}\text { Growth } \\
10^{\circ} \mathrm{C}\end{array}$ & $\begin{array}{c}\text { Indole } \\
\text { production }\end{array}$ & $\begin{array}{c}\text { Pectin } \\
\text { liquefaction }\end{array}$ & $\begin{array}{c}\text { Number (and } \\
\text { percentage) of } \\
\text { strains }\end{array}$ \\
\hline 1 & + & - & - & - & $219(45 \cdot 6)$ \\
2 & - & + & - & - & $133(27 \cdot 7)$ \\
3 & - & + & + & + & $79(16.5)$ \\
4 & - & + & + & - & $40(8 \cdot 3)$ \\
5 & - & - & - & - & $9(1.9)$ \\
\hline
\end{tabular}

$+=$ Positive reaction; $-=$ negative reaction .

* "Faecal coliform" reaction: production of gas in lactose bile-salt broth at $44 \cdot 5^{\circ} \mathrm{C}$. 
table II (tests for linear trend, $\chi^{2}=103 \cdot 21 ; 1$ degree of freedom; $p<0.001$ ). There are, however, significant departures from a linear decrease $\left(\chi^{2}=21 \cdot 73 ; 8\right.$ degrees of freedom; $p<0.01,>0 \cdot 001)$. Strains from the hospital environment and hospital food resembled strains from river water more closely than they resembled strains from clinical specimens in respect of the FC reaction and growth at $10^{\circ} \mathrm{C}$. Although only $32 \%$ of strains from hospital food gave a positive $\mathrm{FC}$ reaction, $67 \%$ of strains from the hospital kitchen-environment were FC positive, indicating a closer similarity in this respect of kitchenenvironment than of hospital food strains to clinical strains.

The variation in the frequency of indole production and pectin liquefaction amongst strains of Klebsiella from each of the 10 different sources was less marked than the difference in FC reaction. It is noteworthy that a high percentage $(69.4 \%)$ of $\mathrm{FC}$-negative strains from clinical material produced indole and liquefied pectin.

In the course of this study the response of each klebsiella strain in each of the four tests was determined on at least two occasions, and positive and negative control strains were included in each batch of tests. Tests of indole production and pectin liquefaction were totally reproducible, but occasionally there were variations in responses of strains in $\mathrm{FC}$ and growth at $10^{\circ} \mathrm{C}$ tests. In these last two tests a few strains gave a strongly positive response on one occasion and a negative, or very weak positive, on another occasion. Such strains were tested a third time, and the more common reaction was taken to be the correct one.

TABLE II

Response of klebsiella strains from different sources to the four tests (see table I)

\begin{tabular}{|c|c|c|c|c|c|}
\hline \multirow{2}{*}{ Sources of strains } & \multirow{2}{*}{$\begin{array}{l}\text { Number } \\
\text { of strains }\end{array}$} & \multicolumn{4}{|c|}{$\begin{array}{l}\text { Number (and percentage) of strains } \\
\text { giving a positive reaction in test: }\end{array}$} \\
\hline & & FC & $\begin{array}{l}\text { Growth } \\
\text { at } 10^{\circ} \mathrm{C}\end{array}$ & $\begin{array}{l}\text { Indole } \\
\text { production }\end{array}$ & $\begin{array}{c}\text { Pectin } \\
\text { liquefaction }\end{array}$ \\
\hline $\begin{array}{l}\text { Pig mastitis } \\
\text { Human infectio }\end{array}$ & $\begin{array}{r}10 \\
113\end{array}$ & $\begin{array}{r}8(80 \cdot 0) \\
77(68 \cdot 1)\end{array}$ & $\begin{array}{r}2(20.0) \\
36(31.9)\end{array}$ & $2(20 \cdot 0)$ & $1(10 \cdot 0)$ \\
\hline Faeces: hospital patients witl & & & & & \\
\hline $\begin{array}{l}\text { klebsiella infections } \\
\text { Faeces: out-patients }\end{array}$ & 40 & $31(77 \cdot 5)$ & $9(22 \cdot 5)$ & $5(12 \cdot 5)$ & $2(5 \cdot 0)$ \\
\hline without & 40 & $24(60 \cdot 0)$ & $16(40 \cdot 0)$ & $8(20 \cdot 0)$ & $3(7 \cdot 5)$ \\
\hline $\begin{array}{l}\text { Hospital-kitchen } \\
\text { environment } \\
\text { Hospital-ward }\end{array}$ & 48 & $32(66 \cdot 7)$ & $16(33 \cdot 3)$ & $8(16 \cdot 7)$ & $5(10 \cdot 4)$ \\
\hline environment & 49 & $19(38 \cdot 8)$ & $30(61 \cdot 2)$ & $22(44 \cdot 9)$ & $18(36 \cdot 7)$ \\
\hline $\begin{array}{l}\text { Hospital food } \\
\text { Flowers in }\end{array}$ & 50 & $16(32 \cdot 0)$ & $34(6$ & $16 i$ & $11(22.0)$ \\
\hline $\begin{array}{l}\text { hospi } \\
\text { Flowers }\end{array}$ & 50 & $1(2 \cdot 0)$ & $49(98 \cdot 0)$ & $12(24 \cdot 0)$ & $3(6 \cdot 0)$ \\
\hline $\begin{array}{l}\text { florists' shops } \\
\text { River water }\end{array}$ & $\begin{array}{l}33 \\
38\end{array}$ & $\begin{array}{l}4(12 \cdot 1) \\
7(18 \cdot 4)\end{array}$ & $\begin{array}{l}29(87.9) \\
31(81 \cdot 6)\end{array}$ & $\begin{array}{l}11(33.3) \\
3(7.9)\end{array}$ & $\begin{array}{l}9(27 \cdot 3) \\
2(5 \cdot 3)\end{array}$ \\
\hline Any & $471^{*}$ & $219(46 \cdot 5)$ & $252(53 \cdot 5)$ & $119(25 \cdot 3)$ & $79(16 \cdot 8)$ \\
\hline
\end{tabular}

* Nine strains that gave negative reactions in all tests are not included. 


\section{Tests of gelatin hydrolysis}

All 119 indole-producing strains of the 480 klebsiellas tested were examined for the hydrolysis of gelatin. Only $20(16 \cdot 8 \%)$ hydrolysed gelatin, all very slowly, though $79(66.4 \%)$ of them liquefied pectin. Each of the 20 gelatinhydrolysing strains also liquefied pectin.

\section{Capsular serotyping and bacteriocine typing}

A wide range of serotypes was represented amongst the strains from each of the 10 sources and no type or types predominated in any one source. Similarly, strains belonging to each of the four groups as determined by the FC, growth at $10^{\circ} \mathrm{C}$, indole- and pectin-liquefaction tests displayed many different serotypes. A smaller percentage of strains from river water were typable serologically $(77 \%)$ than of strains from other sources $(82-100 \%)$. Similar results were obtained from bacteriocine typing; an average of $95 \%$ of strains from each source were typable, and exhibited many different typing patterns.

\section{Antibiotic-sensitivity tests}

The degree of resistance of the klebsiella strains from each of the sources to the 10 antibiotics tested is shown in table III. The most resistant strains were those from clinical specimens, pig mastitis and the faeces of patients with klebsiella infections. In each case many strains were resistant to five or more antibiotics. Strains from the hospital environment, the hospital-kitchen environment and hospital food were less resistant, with few strains resistant to five or more antibiotics. The more sensitive strains were those from the faeces of outpatients with no known infection, river water and flowers from inside and from outside hospital, with over $70 \%$ of the strains from each source being sensitive to eight or more of the antibiotics.

Some $80 \%$ of all strains from each source were resistant to ampicillin, and the relative frequency of resistance to individual antibiotics was rather similar among strains from the various sources. Only $11(2 \cdot 3 \%)$ of the strains were resistant to gentamicin; 10 of these had been isolated from clinical specimens and one from the faeces of a patient with klebsiella infection.

The antibiotic resistance of the strains belonging to cultural groups 1-4 (see table I) is shown in table IV. Strains that did not grow at $10^{\circ} \mathrm{C}$ (group 1) were the most resistant whereas strains from the other three groups, all of which grew at $10^{\circ} \mathrm{C}$, were much less resistant. The patterns of resistance of strains in group 2, which did not produce indole, and groups 3 and 4, both of which did, were similar.

\section{Discussion}

The inverse relationship between the $\mathrm{FC}$ response and growth in nutrient broth at $10^{\circ} \mathrm{C}$ of klebsiella strains was first reported by Naemura and Seidler (1978), who studied klebsiellas from human and clinical material and from 


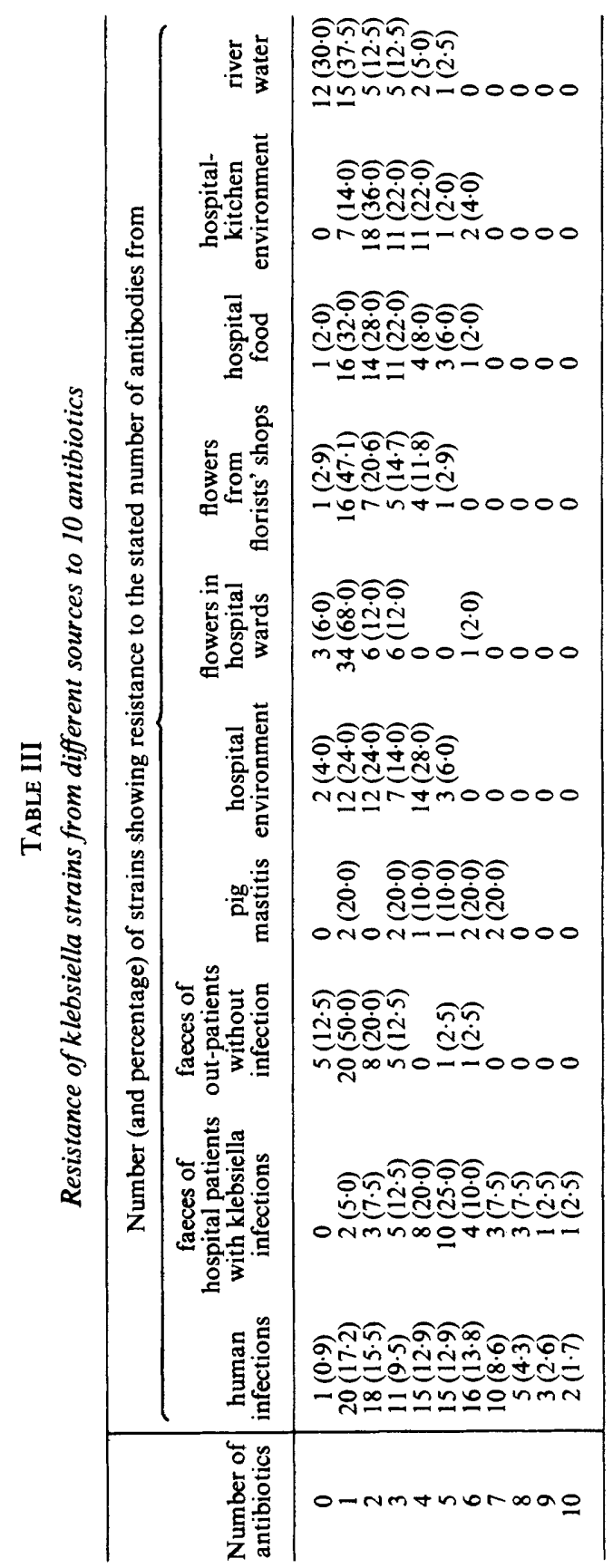


TABLE IV

Antibiotic resistance of klebsiella strains belonging to four cultural groups*

\begin{tabular}{c|cccc}
\hline \multirow{2}{*}{$\begin{array}{c}\text { Number of } \\
\text { antibiotics }\end{array}$} & \multicolumn{4}{c}{$\begin{array}{c}\text { Number (and percentage) of strains showing resistance } \\
\text { to the stated number of antibiotics in group }\end{array}$} \\
\cline { 2 - 5 } & 1 & 2 & 3 & 4 \\
\hline 0 & $4(1 \cdot 8)$ & $14(10 \cdot 5)$ & $5(6 \cdot 3)$ & $1(2 \cdot 5)$ \\
1 & $25(11 \cdot 4)$ & $74(55 \cdot 6$ & $21(26 \cdot 6)$ & $23(57 \cdot 5)$ \\
2 & $31(14 \cdot 2)$ & $26(19 \cdot 5)$ & $27(34 \cdot 2)$ & $5(12 \cdot 5)$ \\
3 & $39(17 \cdot 8)$ & $11(8 \cdot 3)$ & $7(8 \cdot 9)$ & $7(17 \cdot 5)$ \\
4 & $44(20 \cdot 1)$ & $6(4 \cdot 5)$ & $9(11 \cdot 4)$ & $1(2 \cdot 5)$ \\
5 & $29(13 \cdot 2)$ & 0 & $5(6 \cdot 3)$ & $2(5 \cdot 0)$ \\
6 & $21(9 \cdot 6)$ & $2(1 \cdot 5)$ & $3(3 \cdot 8)$ & 0 \\
7 & $12(5 \cdot 5)$ & 0 & $2(2 \cdot 5)$ & $1(2 \cdot 5)$ \\
8 & $7(3 \cdot 2)$ & 0 & 0 & 0 \\
9 & $4(1 \cdot 8)$ & 0 & 0 & 0 \\
10 & $3(1 \cdot 4)$ & 0 & 0 & 0 \\
Total & 219 & 133 & 79 & 40 \\
\hline
\end{tabular}

* See table I.

various environmental sources. In the present study the same relationship was demonstrated for klebsiellas isolated from different sources, including a variety of sources in the hospital environment.

The great majority of klebsiella strains from the hospital-ward environment and from flowers in hospital wards were FC negative, indicating that hospital patients may be exposed to large numbers of environmentally derived klebsiellas. The fact that most klebsiella strains of clinical origin are FC positive suggests that klebsiellas in the hospital-ward environment may not be of great importance in causing human infection. There is, however, a possibility that strains may change from FC negative to FC positive when introduced into a different environment. Although such a change has not been demonstrated, Knittel et al. (1977) noted a decrease in the minimum lethal dose for mice of two klebsiella strains isolated from human infections after they had been passaged many times in sterile wood-pulp effluent.

The position of klebsiella strains from the hospital-kitchen environment was less clear than that of strains from the hospital-ward environment and hospital food; $64 \%$ of strains from the kitchen environment were $\mathrm{FC}$ positive whereas only $32 \%$ of strains isolated from food prepared in the same kitchen showed a positive FC response. More work is needed to clarify the sources of klebsiellas found in the kitchen environment, although it is possible that some may be animal strains introduced into the kitchen on raw meat.

Almost a quarter of the klebsiella strains studied were indole positive, and a higher proportion of strains from clinical specimens and the hospital-ward environment than from river water produced indole. Indole production in klebsiellas has been correlated with the liquefaction of gelatin (Lautrop, 1956; Stenzel, Burger and Mannheim, 1972) and pectin (von Riesen, 1976), and such strains have been termed Klebsiella oxytoca. We found a distinct group of klebsiella strains that were FC negative and produced indole and liquefied 
pectin. There was evidence that these strains may be more significant in causing infections than other FC-negative strains. The great majority of FC-negative klebsiellas of human or animal clinical origin were indole and pectin positive, as were the majority of strains from the hospital-ward environment. In contrast, the majority of FC-negative strains from the natural environment were indole and pectin negative.

A relationship has been suggested between indole production and antibiotic resistance in Klebsiella (Klein, Spindler and Matsen, 1975), with indoleproducing strains more often having wide patterns of resistance than indolenegative strains. We found that there was no significant difference in the number of antibiotics to which FC-negative indole-positive and FC-negative indole-negative strains were resistant, but that FC-positive strains exhibited more resistances than did FC-negative strains whether indole positive or indole negative.

Strains from human infections, from the faeces of hospital patients with klebsiella infections and from pig mastitis were more often resistant to five or more antibiotics than were strains from the other sources examined. In general, the number of resistances per strain among isolates from different sources increased with increase in frequency of a positive $\mathrm{FC}$ response. The only exception was with the two groups of strains from faeces. A similar percentage of strains from these two groups were FC positive, but strains from faeces of hospital patients with klebsiella infections were resistant to more antibiotics than were strains from the faeces of outpatients with no known infection.

The division of klebsiellas into groups by their reactions in FC, growth at $10^{\circ} \mathrm{C}$, indole- and pectin-liquefaction tests may prove to be very useful in assessing the significance of klebsiella strains found in the environment both inside and outside hospital, and in farm produce (Duncan and Razzell, 1972), in relation to infection in hospital patients and in farm animals.

\section{SUMMARY}

The ability to form gas in lactose bile-salt broth at $44.5^{\circ} \mathrm{C}$ (the "faecal coliform" or FC test), growth in nutrient broth at $10^{\circ} \mathrm{C}$, indole production and pectin liquefaction were studied in 480 strains of Klebsiella isolated from human and animal infections, from various sites in the hospital environment and hospital food, and from river water and flowers. A positive FC response was correlated inversely with the ability to grow at $10^{\circ} \mathrm{C}$. Most strains of human and animal clinical origin were FC positive, whereas strains from water and flowers were mainly FC negative. The frequency of a positive FC response in strains from the hospital environment fell between these two extremes. The production of indole and liquefaction of pectin by klebsiellas was correlated directly with the ability to grow at $10^{\circ} \mathrm{C}$ and a negative FC response. Nearly all of the strains could be allocated to one of four groups on the basis of these tests.

The capsular serotype, bacteriocine-inhibition patterns and antibiotic sensitivities of the strains were examined. No correlation was evident between 
the first two properties and klebsiellas from any particular source. Strains of clinical origin were more often resistant to five or more antibiotics than were strains from the hospital environment, which in turn showed a greater frequency of antibiotic resistance than did strains from river water and flowers.

We are grateful to Dr J. E. T. Jones for providing strains from pig mastitis and to $\mathrm{Mr} \mathrm{W}$. G. Starkey and Mrs Mary E. Walker for expert technical assistance. Our thanks are also due to Mrs J. Siegerstetter, Department of Community Medicine and General Practice, University of Leeds for statistical assistance. This investigation was supported in part by a Project Grant from the Medical Research Council.

\section{REFERENCES}

American Public Health Association, 1976. Standard methods for the examination of water and wastewater, 14th ed. APHA: Washington.

Braman, S. K., Eberhart, R. J., Asbury, M. A. and Hermann, G. J., 1973. Capsular types of Klebsiella pneumoniae associated with bovine mastitis. J. Am. vet. med. Ass., 162, 109.

Brown, C. AND SeIDler, R. J., 1973. Potential pathogens in the environment: Klebsiella pneumoniae, a taxonomic and ecological enigma. Appl. Microbiol., 25, 900.

Cooke, E. M., Brayson, J. C., Edmondson, A. S. And Hall, D., 1979a. An investigation into the incidence and sources of klebsiella infections in hospital patients. J. Hyg., Camb., 82, 473.

Cooke, E. M., Pool, R., Brayson, J. C., Edmondson, A. S., Munro, M. E. and Shinebaum, R. $1979 b$. Further studies on the sources of Klebsiella aerogenes infections in hospital patients. J. Hyg., Camb., 83, 391.

Cooke, E. M., Sazegar, T., Edmondson, A. S., Brayson, J. C. and Hall, D. 1980. Klebsiella species in hospital food and kitchens: a source of organisms in the bowel of patients. $J$. Hyg., Camb., 84, 97.

Cowan, S. T. 1974. Cowan and Steel's manual for the identification of medical bacteria, 2nd ed. Cambridge University Press: Cambridge.

Curie, K., Speller, D. C. E., Simpson, R. A., Stephens, M. and Cooke, D. I. 1978. A hospital epidemic caused by a gentamicin-resistant Klebsiella aerogenes. J. Hyg., Camb., 80, 115.

Donovan, T. J. 1966. A Klebsiella screening medium. J. med. Lab. Technol., 23, 194.

Dufour, A. P. AND CABELli, V. J. 1976. Characteristics of Klebsiella from textile finishing plant effluents. J. Wat. Pollut. Control Fed., 48, 872.

DUNCAN, D. W. AND RazzeLL, W. E. 1972. Klebsiella biotypes among coliforms isolated from forest environments and farm produce. Appl. Microbiol., 24, 933.

EdmondSON, A. S. AND COOKE, E. M. 1979. The development and assessment of a bacteriocin typing method for Klebsiella. J. Hyg., Camb., 82, 207.

EDWARDS, P. R. AND EwING, W. H. 1972. Identification of Enterobacteriaceae, 3rd ed. Burgess: Minneapolis, p. 351.

Klein, D., Spindler, J. A. ANd Matsen, J. M. 1975. Relationship of indole production and antibiotic susceptibility in the Klebsiella bacillus. J. clin. Microbiol., 2, 425.

KNITTEL, M. D. 1975. Occurrence of Klebsiella pneumoniae in surface waters. Appl. Microbiol., 29, 595.

Knittel, M. D., Seidler, R. J., Eby, C. and Cabe, L. M. 1977. Colonisation of the botanical environment by Klebsiella isolates of pathogenic origin. Appl. envir. Microbiol., 34, 557.

LAUTroP, H. 1956. Gelatin-liquefying Klebsiella strains (Bacterium oxytocum (Flügge)). Acta path. microbiol. scand., 39, 375.

NaEmURA, L. G. AND SeIDleR, R. J. 1978. Significance of low-temperature growth associated with the fecal coliform response, indole production, and pectin liquefaction in Klebsiella. Appl. envir. Microbiol., 35, 392.

Price, D. J. E. AND Sleigh, J. D. 1970. Control of infection due to Klebsiella aerogenes in a neurosurgical unit by withdrawal of all antibiotics. Lancet, 2, 1213. 
RIESEN, V. L. von 1976. Pectinolytic, indole-positive strains of Klebsiella pneumoniae. Int. J. syst. Bact., 26, 143.

Seidler, R. J., Knittel, M. D. And Brown, C. 1975. Potential pathogens in the environment: cultural reactions and nucleic acid studies on Klebsiella pneumoniae from clinical and environmental sources. Appl. Microbiol., 29, 819.

Stenzel, W., Burger, H. and Mannheim, W. 1972. On the systematics and differential diagnosis of the Klebsiella group under special consideration of the so-called oxytocum types. Zentbl. Bakt. ParasitKde, I. Abt. Orig., 219, 193 (in German).

STOKES, E. J. 1975. Clinical bacteriology, 4th ed. Arnold: London. 